\title{
Gas-sensitive properties of thin film heterojunction structures based on $\mathrm{Fe}_{2} \mathrm{O}_{3}-\mathrm{In}_{2} \mathrm{O}_{3}$ nanocomposites
}

\author{
M. Ivanovskaya a, , D. Kotsikau ${ }^{\text {a }}$, G. Faglia ${ }^{\text {b }}$ \\ P. Nellic, S. Irkaev ${ }^{\mathrm{d}}$

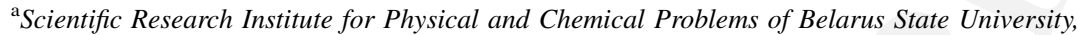 \\ Leningradskaya St. 14, 220050 Minsk, Belarus \\ b INFM-Gas Sensors Laboratory, University of Brescia, Via Valotti 9, 25133 Brescia, Italy \\ ${ }^{\mathrm{c}}$ Department of Engineering, University of Bergamo, viale Marconi, 524044 Dalmine (BG), Italy \\ ${ }^{\mathrm{d}}$ Russian Academy of Science, Institute for Analytical Instrumentation, Ryzhskii Av. 26, 198103 \\ St. Petersburg, Russia
}

\section{Introduction}

The existing literature reports that the sensitivity of ceramic sensors based on $\mathrm{Fe}_{2} \mathrm{O}_{3}$ layers to reducing gases is rather low [1-3]. However, the doping of $\mathrm{Fe}_{2} \mathrm{O}_{3}$ with quadrivalent metal ions ( $\mathrm{Sn}, \mathrm{Ti}, \mathrm{Zr}$ ) as well as the modification of this material with $\mathrm{SO}_{4}{ }^{2-}$ ions can significantly enhance the gas-sensitive properties of the corresponding sensors towards ethanol and hydrocarbons [3]. In particular, the addition of $\mathrm{Fe}_{2} \mathrm{O}_{3}$ to $\mathrm{SnO}_{2}$ thick films leads to an increasing response to ethanol [4]. There are also some papers concerning the effect of $\mathrm{Fe}_{2} \mathrm{O}_{3}$ additives on the properties of $\mathrm{In}_{2} \mathrm{O}_{3}$ based sensors; for example, the sputtering of a $\mathrm{Fe}_{2} \mathrm{O}_{3}$ layer over $\mathrm{In}_{2} \mathrm{O}_{3}$ thin film increases its sensitivity to $\mathrm{O}_{3}$ and reduces the optimal operating temperature [5].
A considerable improvement of $\operatorname{In}_{2} \mathrm{O}_{3}$ thin film sensors with respect to $\mathrm{O}_{3}$ by doping with $\gamma-\mathrm{Fe}_{2} \mathrm{O}_{3}$ is reported by Gutman et al. [6]; the influence of $\alpha-\mathrm{Fe}_{2} \mathrm{O}_{3}$ additives on $\mathrm{In}_{2} \mathrm{O}_{3}$ behavior is negligible. The high activity of $\gamma$ $\mathrm{Fe}_{2} \mathrm{O}_{3}-\mathrm{In}_{2} \mathrm{O}_{3}$ composite in the $\mathrm{O}_{3}$ detection can be associated with the specific features of $\gamma-\mathrm{Fe}_{2} \mathrm{O}_{3}$ structure, like the presence of metal cation vacancies within the crystal lattice and the readiness of $\mathrm{Fe}^{2+} \leftrightarrow \mathrm{Fe}^{3+}$ transformation under exposure by gaseous species. Nevertheless, the available data are not sufficient in order to realize if iron oxides are suitable materials for gas sensing applications.

As it is known, $\gamma-\mathrm{Fe}_{2} \mathrm{O}_{3}$ is characterized by a comparatively low thermal stability with respect to $\gamma-\mathrm{Fe}_{2} \mathrm{O}_{3} \rightarrow \alpha$ $\mathrm{Fe}_{2} \mathrm{O}_{3}$ phase transformation that ordinarily occurs at $485{ }^{\circ} \mathrm{C}$. This peculiarity of $\gamma-\mathrm{Fe}_{2} \mathrm{O}_{3}$ limits its use as long-term stable gas-sensitive material.

The gas-sensitive properties of thin film layers of complex structure based on both $\gamma-\mathrm{Fe}_{2} \mathrm{O}_{3}$ and $\alpha-\mathrm{Fe}_{2} \mathrm{O}_{3}$ have been extensively characterized in this paper. The use of systems with complex composition allows us to 
increase significantly the thermal stability of $\gamma-\mathrm{Fe}_{2} \mathrm{O}_{3}$ phase (up to $650{ }^{\circ} \mathrm{C}$ ) in $\gamma-\mathrm{Fe}_{2} \mathrm{O}_{3}-\mathrm{In}_{2} \mathrm{O}_{3}$ composite and to modify its gas-sensitive characteristics by imparting to the sensors the required sensitive and dynamical features.

\section{Experimental}

The gas-sensitive properties of thin film double-layer sensors based on $\mathrm{Fe}_{2} \mathrm{O}_{3}$, and $\mathrm{Fe}_{2} \mathrm{O}_{3}-\mathrm{In}_{2} \mathrm{O}_{3}$ ( $\mathrm{Fe}: \mathrm{In}=9: 1$ and $1: 1, \mathrm{~mol})$ were investigated; sensor response values to $\mathrm{CH}_{3} \mathrm{OH}, \mathrm{C}_{2} \mathrm{H}_{5} \mathrm{OH}(100-500 \mathrm{ppm}), \mathrm{CH}_{4}, \mathrm{CO}$ (50 ppm) ozone (200 ppb) and $\mathrm{NO}_{2}(0.5-5 \mathrm{ppm})$ were obtained.

The sensitive elements were formed from the stabilized sols of the corresponding metal hydroxides which were prepared by the sol-gel technique. The procedure of sol preparation used in this study consisted of the following steps:

(i) forced hydrolysis of inorganic metal salt solution $\left(\mathrm{FeCl}_{2}, \mathrm{In}\left(\mathrm{NO}_{3}\right)_{3}\right)$ with a basic agent $\left(\mathrm{NH}_{3}\right)$,

(ii) precipitation of metal hydroxide followed by its separation,

(iii) formation of sol through peptization of the deposit with a peptizing agent or as a result of selfpeptization.

The $\alpha-\mathrm{Fe}_{2} \mathrm{O}_{3}-\mathrm{In}_{2} \mathrm{O}_{3}$ composite was prepared by combined precipitation of $\mathrm{Fe}(\mathrm{OH})_{2}$ and $\mathrm{In}(\mathrm{OH})_{3}$ hydroxides followed by their oxidation with oxygen. A flow of air was passed through the corresponding suspension during $5-6 \mathrm{~h}$ at $30{ }^{\circ} \mathrm{C}$ to perform the material oxidization. In contrast, $\gamma-\mathrm{Fe}_{2} \mathrm{O}_{3}-\mathrm{In}_{2} \mathrm{O}_{3}$ sample was obtained by mixing of individual sols of $\gamma-\mathrm{Fe}_{2} \mathrm{O}_{3}$ and $\operatorname{In}(\mathrm{OH})_{3}$ in the required proportions.

Sols were deposited onto polycrystalline $\mathrm{Al}_{2} \mathrm{O}_{3}$ substrates ( $3 \mathrm{~mm} \times 3 \mathrm{~mm} \times 0.25 \mathrm{~mm}$ size) with Pt interdigital electrode deposited on the front side and Pt meander heater on the back side.

An $\mathrm{In}_{2} \mathrm{O}_{3}$ sub-layer was preliminary deposited onto the substrate in order to form the heterojunction structure and provide suitable sensor conductance. A single-layer sensor, consisting only of $\mathrm{In}_{2} \mathrm{O}_{3}$ or $\mathrm{Fe}_{2} \mathrm{O}_{3}$ also were studied in parallel for comparison. The samples were dried at $25^{\circ} \mathrm{C}$ and annealed at $300{ }^{\circ} \mathrm{C}$ in air.

The sensors were then mounted on a TO8 standard cases and were put inside the a chamber for the DC electrical measurements in presence of fixed gas concentrations and RH levels.

The sensor response was calculated as $\Delta G / G_{\text {air }}$ at $\mathrm{CH}_{3} \mathrm{OH}$, $\mathrm{C}_{2} \mathrm{H}_{5} \mathrm{OH}, \mathrm{CH}_{4}, \mathrm{CO}$ detection and as $\Delta G / G_{\text {gas }}$ at $\mathrm{NO}_{2}$ and $\mathrm{O}_{3}$ detection, where $G$ is the electrical conductance of sensitive layer.

The structure of the single oxides $\left(\mathrm{Fe}_{2} \mathrm{O}_{3}, \mathrm{In}_{2} \mathrm{O}_{3}\right)$ and nanocomposites $\left(\mathrm{Fe}_{2} \mathrm{O}_{3}-\mathrm{In}_{2} \mathrm{O}_{3}\right)$ were characterized by means of X-ray diffraction (XRD), transmission electron micros- copy (TEM) and Mössbauer spectroscopy. The resonance spectra were recorded and processed in a commercial SM2201 Mössbauer spectrometer. The measurements reported here were performed at $298 \mathrm{~K}$ using a $15 \mathrm{mCi}{ }^{57} \mathrm{Co}(\mathrm{Rh})$ source.

\section{Results and discussion}

\subsection{Gas-sensitive properties}

As it was found, $\gamma-\mathrm{Fe}_{2} \mathrm{O}_{3}-\mathrm{In}_{2} \mathrm{O}_{3}(9: 1) / \mathrm{In}_{2} \mathrm{O}_{3}$ and $\alpha$ $\mathrm{Fe}_{2} \mathrm{O}_{3}-\mathrm{In}_{2} \mathrm{O}_{3} \quad(9: 1) / \mathrm{In}_{2} \mathrm{O}_{3}$ sensors are characterized by high sensitivity to $\mathrm{O}_{3}$ and $\mathrm{NO}_{2}$, respectively, over a low temperature range $\left(70-135{ }^{\circ} \mathrm{C}\right)$, as it is reported in Fig. 1a and $b$. These response values are greater than those ones typical for a single-layer sensors based on $\mathrm{In}_{2} \mathrm{O}_{3}$ and $\mathrm{Fe}_{2} \mathrm{O}_{3}$.

The response values of $\alpha-\mathrm{Fe}_{2} \mathrm{O}_{3}$ and $\gamma-\mathrm{Fe}_{2} \mathrm{O}_{3}$ samples to $\mathrm{O}_{3}$ and $\mathrm{NO}_{2}$ at various operating temperatures are reported in Table 1. It is clearly seen from these data that $\gamma-\mathrm{Fe}_{2} \mathrm{O}_{3}-\mathrm{In}_{2} \mathrm{O}_{3}(9: 1) / \mathrm{In}_{2} \mathrm{O}_{3}$ sensor shows a high conductance variation in the $\mathrm{O}_{3}$ atmosphere at $135{ }^{\circ} \mathrm{C}$, while its response to $\mathrm{NO}_{2}$ at the same temperature is negligible. In contrast, $\alpha-\mathrm{Fe}_{2} \mathrm{O}_{3}-\mathrm{In}_{2} \mathrm{O}_{3}(9: 1) / \mathrm{In}_{2} \mathrm{O}_{3}$ sample shows a good response to $\mathrm{NO}_{2}$ in the temperature range $50-100{ }^{\circ} \mathrm{C}$ together with a rather low one to $\mathrm{O}_{3}$. These distinctions, observed in the behavior of both composites, can be used for a selective analysis of $\mathrm{O}_{3}$ and $\mathrm{NO}_{2}$ in the gas mixture.

Generally, the sensitivity of $\operatorname{In}_{2} \mathrm{O}_{3}$ and $\mathrm{SnO}_{2}$ films to $\mathrm{O}_{3}$ is lower in comparison with its sensitivity towards $\mathrm{NO}_{2}[7,8]$. In contrast, $\mathrm{Fe}_{2} \mathrm{O}_{3}-\mathrm{In}_{2} \mathrm{O}_{3}$ layers are characterized by a higher sensitivity to $\mathrm{O}_{3}$ than to $\mathrm{NO}_{2}$. Moreover, the indicated compositions show better $\mathrm{NO}_{2}$ detection performances than the previously investigated sensors based on $\operatorname{In}_{2} \mathrm{O}_{3}-\mathrm{NiO}$ [9] and $\mathrm{In}_{2} \mathrm{O}_{3}-\mathrm{MoO}_{3}$ thin films [7].

It should be noted that the sensors show insufficiently rapid response and rather long recovery time at low operating temperatures. Isothermal response of $\alpha-\mathrm{Fe}_{2} \mathrm{O}_{3}-\mathrm{In}_{2} \mathrm{O}_{3}$ (9:1)/ $/ \mathrm{In}_{2} \mathrm{O}_{3}$ double-layer to $5 \mathrm{ppm} \mathrm{NO} \mathrm{NO}_{2}$ is represented in

Table 1

The comparison of response values of sensors based on both $\alpha-\mathrm{Fe}_{2} \mathrm{O}_{3}$ and $\gamma-\mathrm{Fe}_{2} \mathrm{O}_{3}$ to $\mathrm{O}_{3}$ and $\mathrm{NO}_{2}$

\begin{tabular}{lcccc}
\hline $\begin{array}{l}\text { Detected } \\
\text { gas }\end{array}$ & $C_{\text {gas }}(\mathrm{ppb})$ & $T\left({ }^{\circ} \mathrm{C}\right)$ & \multicolumn{2}{l}{$\Delta G / G_{\text {gas }}$} \\
\cline { 3 - 5 } & & & $\begin{array}{l}\alpha-\mathrm{Fe}_{2} \mathrm{O}_{3}-\mathrm{In}_{2} \mathrm{O}_{3} \\
(9: 1) / \mathrm{In}_{2} \mathrm{O}_{3}\end{array}$ & $\begin{array}{l}\gamma-\mathrm{Fe}_{2} \mathrm{O}_{3}-\mathrm{In}_{2} \mathrm{O}_{3} \\
(9: 1) / \mathrm{In}_{2} \mathrm{O}_{3}\end{array}$ \\
\hline $\mathrm{O}_{3}$ & 100 & 100 & 65 & 130 \\
& 100 & 135 & 450 & 8670 \\
$\mathrm{NO}_{2}$ & 500 & 100 & 65 & 15 \\
& 500 & 135 & 75 & 10 \\
& 5000 & 100 & 600 & 90 \\
& 5000 & 135 & 440 & 50 \\
\hline
\end{tabular}

\section{(1)}

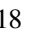

\section{象} 21 
ARTICLE IN PRESS

M. Ivanovskaya et al./Sensors and Actuators B 7031 (2003) 1-9

3
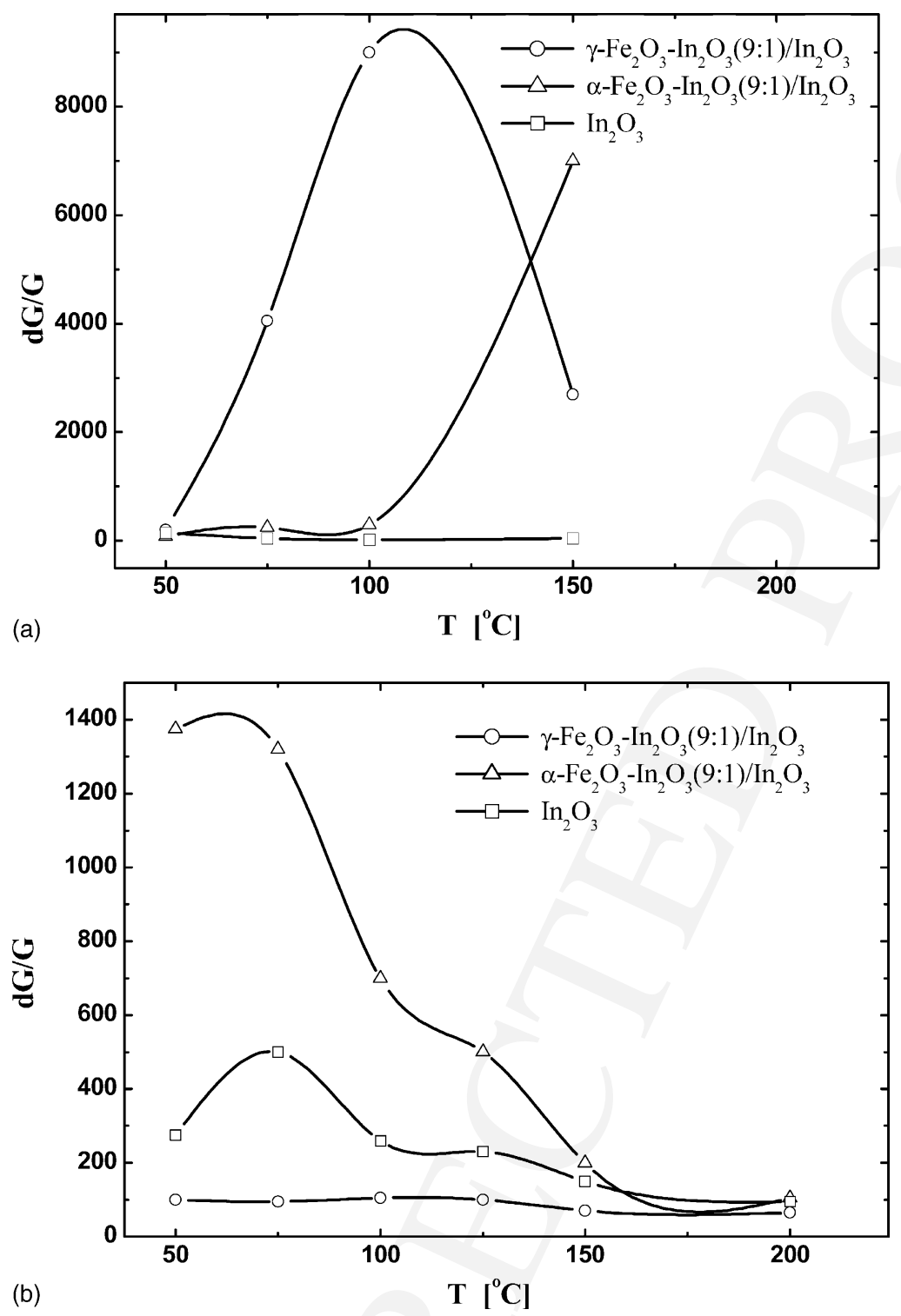

Fig. 1. Temperature-dependent responses of $\mathrm{In}_{2} \mathrm{O}_{3}$ based sensors to (a) $200 \mathrm{ppb} \mathrm{O}_{3}$ and (b) 5 ppm $\mathrm{NO}_{2}$.

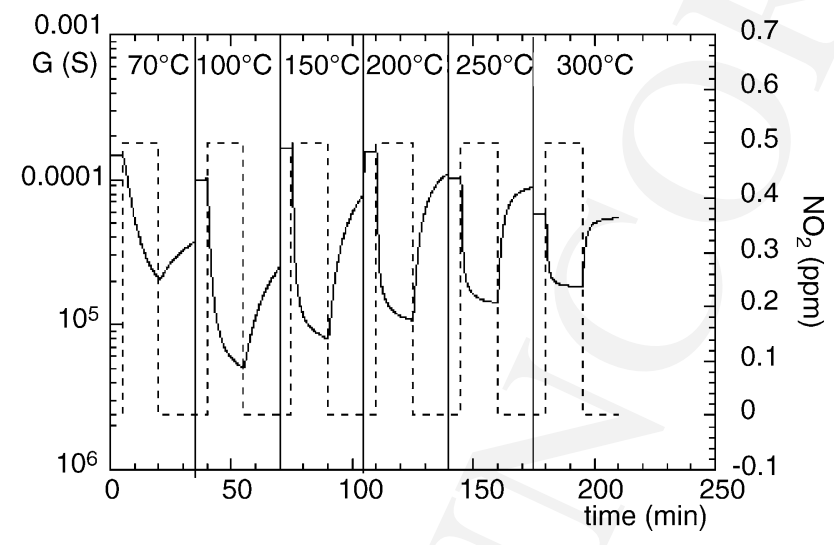

Fig. 2. Isothermal response of $\alpha-\mathrm{Fe}_{2} \mathrm{O}_{3}-\mathrm{In}_{2} \mathrm{O}_{3}(9: 1) / \mathrm{In}_{2} \mathrm{O}_{3}$ thin film sensor between 70 and $300{ }^{\circ} \mathrm{C}$ to 5 ppm $\mathrm{NO}_{2}$ in $50 \% \mathrm{RH}$.
Table 2

Responses and dynamical parameters of $\operatorname{In}_{2} \mathrm{O}_{3}$ and $\alpha-\mathrm{Fe}_{2} \mathrm{O}_{3}-\mathrm{In}_{2} \mathrm{O}_{3}$ (9:1)/ $\mathrm{In}_{2} \mathrm{O}_{3}$ thin film sensors to 5 ppm $\mathrm{NO}_{2}$ vs. temperature in the range of 55$250{ }^{\circ} \mathrm{C}$

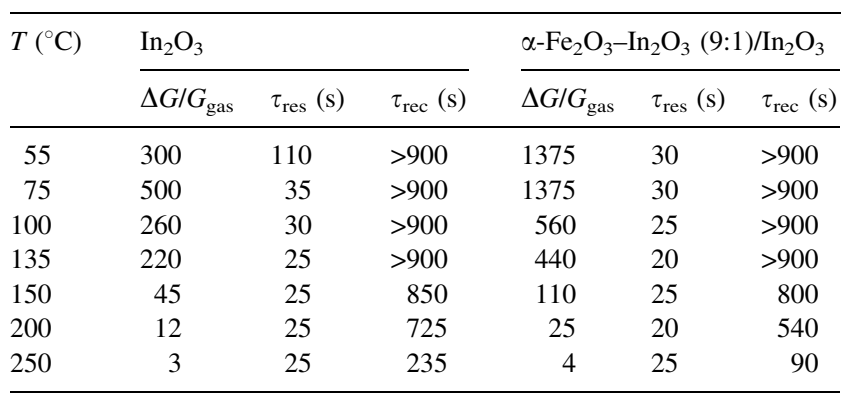




\section{ARTICLE IN PRESS}

M. Ivanovskaya et al./Sensors and Actuators B 7031 (2003) 1-9

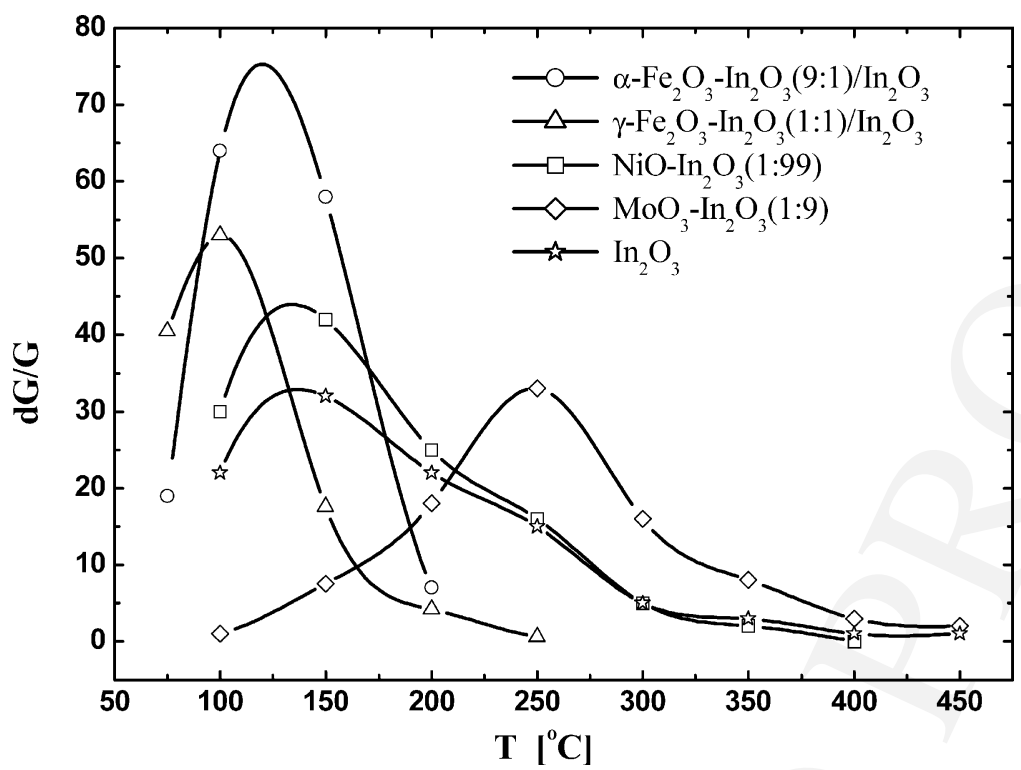

Fig. 3. Comparison of sensitivity of $\mathrm{In}_{2} \mathrm{O}_{3}$ based sensors doping with oxides of different metals to $1 \mathrm{ppm}^{\mathrm{NO}} \mathrm{N}_{2}$.

Fig. 2. The responses and dynamical characteristics of $\operatorname{In}_{2} \mathrm{O}_{3}$ and $\alpha-\mathrm{Fe}_{2} \mathrm{O}_{3}-\mathrm{In}_{2} \mathrm{O}_{3}(9: 1) / \mathrm{In}_{2} \mathrm{O}_{3}$ thin film sensors are compared in Table 2.

Fig. 3 shows the dependence of the response values to $\mathrm{NO}_{2}$ on the operating temperature for sensors with different composition of the sensitive layer. As it is seen from these curves, $\mathrm{Fe}_{2} \mathrm{O}_{3}-\mathrm{In}_{2} \mathrm{O}_{3}$ sensors have not only the greatest signals, but they can operate properly at relatively low temperatures.

$\mathrm{Fe}_{2} \mathrm{O}_{3}-\mathrm{In}_{2} \mathrm{O}_{3} / \mathrm{In}_{2} \mathrm{O}_{3}$ and $\mathrm{Fe}_{2} \mathrm{O}_{3}-\mathrm{In}_{2} \mathrm{O}_{3}$ sensors posses poor responses to low concentration of $50 \mathrm{ppm} \mathrm{CO}$, as it is shown in Fig. 4; they are also almost insensitive both to $\mathrm{CH}_{4}$ and $\mathrm{NH}_{3}$.
It is important to note that all double-layer sensors are much more sensitive towards alcohol $\left(\mathrm{C}_{2} \mathrm{H}_{5} \mathrm{OH}, \mathrm{CH}_{3} \mathrm{OH}\right)$ vapors than single-layer $\mathrm{In}_{2} \mathrm{O}_{3}$ and $\mathrm{Fe}_{2} \mathrm{O}_{3}$ samples; the maximum response is showed by $\gamma-\mathrm{Fe}_{2} \mathrm{O}_{3}-\mathrm{In}_{2} \mathrm{O}_{3}$ composite. Temperature dependent responses of $\gamma-\mathrm{Fe}_{2} \mathrm{O}_{3}-\mathrm{In}_{2} \mathrm{O}_{3}$ and $\mathrm{In}_{2} \mathrm{O}_{3}$ sensors are represented in Fig. 5.

One should also point out that $\mathrm{Fe}_{2} \mathrm{O}_{3}$-containing films are insensitive to $\mathrm{O}_{3}$ and $\mathrm{NO}_{2}$ over the temperature range of the most efficient ethanol detection $\left(250-400{ }^{\circ} \mathrm{C}\right)$; at the same time, their sensitivity regarding ethanol is negligible at $50-150{ }^{\circ} \mathrm{C}$, when $\mathrm{O}_{3}$ and $\mathrm{NO}_{2}$ interaction with oxide surface has the maximum value. An increase of the $\operatorname{In}_{2} \mathrm{O}_{3}$ content within $\mathrm{Fe}_{2} \mathrm{O}_{3}-\mathrm{In}_{2} \mathrm{O}_{3}$ composite up to $50 \mathrm{~mol} \%$

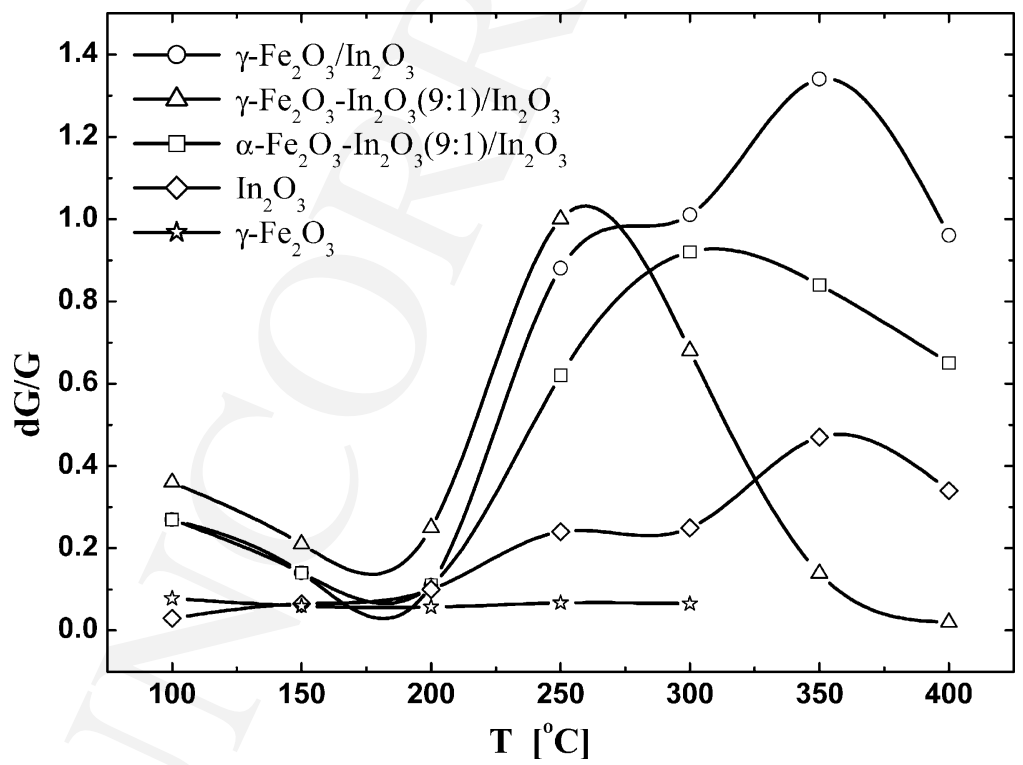

Fig. 4. Temperature-dependent responses of the layers of different composition to $50 \mathrm{ppm}$ CO. 


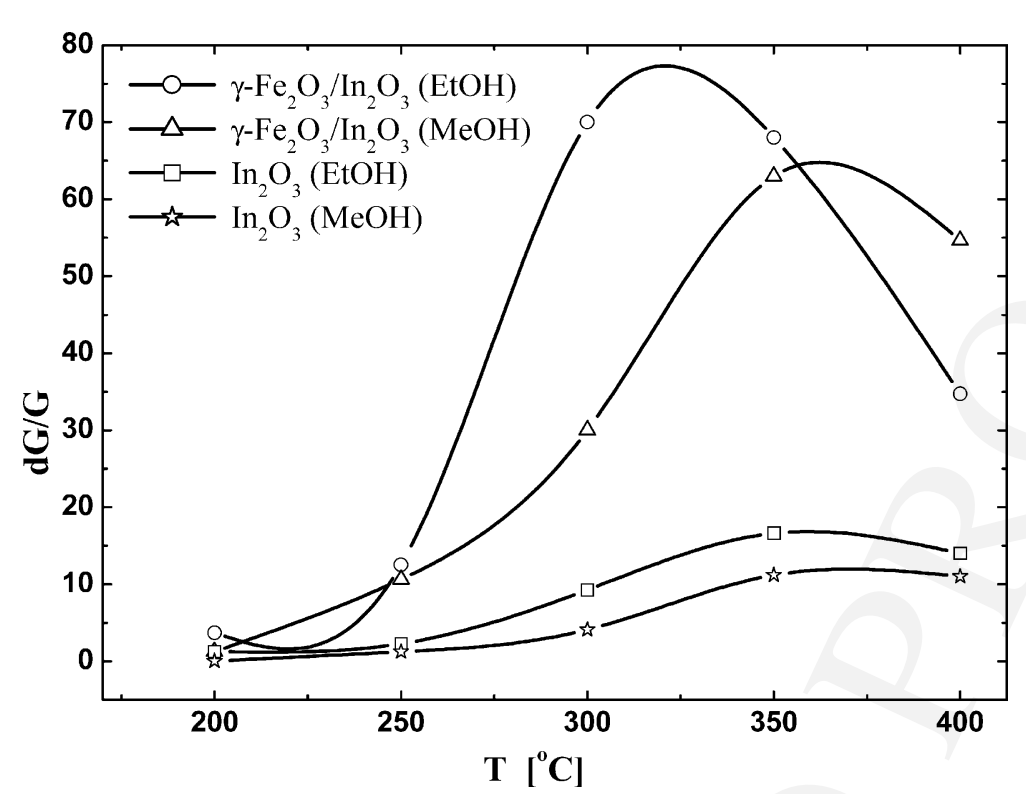

Fig. 5. Temperature-dependent responses of $\mathrm{In}_{2} \mathrm{O}_{3}$ and $\mathrm{Fe}_{2} \mathrm{O}_{3}$ based single- and double-layer sensors to 100 ppm $\mathrm{C}_{2} \mathrm{H}_{5} \mathrm{OH}$ and 100 ppm $\mathrm{CH}_{3} \mathrm{OH}$.

leads to the growth of the sensor responses both to $\mathrm{NO}_{2}$ and ethanol.

The comparison of gas-sensitive behavior of both singleand double-layer $\mathrm{Fe}_{2} \mathrm{O}_{3}$ species regarding $\mathrm{NO}_{2}, \mathrm{CO}$ and ethanol is presented in Table 3 . In the case of $\mathrm{O}_{3}$, the response of single $\mathrm{Fe}_{2} \mathrm{O}_{3}$ layer was negligible and irreproducible.

Referring to the results of functional and structural investigations, we can recommend a series of $\mathrm{Fe}_{2} \mathrm{O}_{3}-\mathrm{In}_{2} \mathrm{O}_{3}$ samples with different structural and phase state to be used as advanced materials for $\mathrm{O}_{3}, \mathrm{NO}_{2}$ and $\mathrm{C}_{2} \mathrm{H}_{5} \mathrm{OH}$ detection. The particular compositions, dispersion, structural and phase features are listed in Table 4. The first three sensors appeared absolutely selective to $\mathrm{O}_{3}, \mathrm{NO}_{2}$ and $\mathrm{C}_{2} \mathrm{H}_{5} \mathrm{OH}$ at the indicated operating temperature. The fourth one can be used for $\mathrm{NO}_{2}$ detection (low temperatures) as well as for $\mathrm{C}_{2} \mathrm{H}_{5} \mathrm{OH}$ analysis (higher temperatures).

\subsection{Structural characterization}

Both TEM and XRD data give evidence that all the films studied appear to be nanosized systems.

Table 3

The comparison of gas-sensitive behavior of $\mathrm{In}_{2} \mathrm{O}_{3}, \mathrm{Fe}_{2} \mathrm{O}_{3}$ and $\mathrm{Fe}_{2} \mathrm{O}_{3}-$ $\mathrm{In}_{2} \mathrm{O}_{3}$ thin films

\begin{tabular}{|c|c|c|c|c|c|c|}
\hline \multirow[t]{2}{*}{ Sensor } & \multicolumn{2}{|c|}{$\mathrm{NO}_{2}, 5 \mathrm{ppm}$} & \multicolumn{2}{|c|}{$\mathrm{CO}, 50 \mathrm{ppm}$} & \multicolumn{2}{|c|}{$\mathrm{C}_{2} \mathrm{H}_{5} \mathrm{OH}, 100 \mathrm{ppm}$} \\
\hline & $\Delta G / G_{\mathrm{gas}}$ & $T\left({ }^{\circ} \mathrm{C}\right)$ & $\Delta G / G_{\text {air }}$ & $T\left({ }^{\circ} \mathrm{C}\right)$ & $\Delta G / G_{\text {air }}$ & $T\left({ }^{\circ} \mathrm{C}\right)$ \\
\hline $\mathrm{In}_{2} \mathrm{O}_{3}$ & 40 & 100 & 0.45 & 350 & 15 & 350 \\
\hline $\mathrm{Fe}_{2} \mathrm{O}_{3}$ & 5 & 100 & 0.1 & 250 & 15 & 350 \\
\hline $\mathrm{Fe}_{2} \mathrm{O}_{3}-\mathrm{In}_{2} \mathrm{O}_{3}$ & 65 & 135 & 1.25 & 350 & 65 & 300 \\
\hline
\end{tabular}

Table 4 displays the average grain size of the samples $\left(300{ }^{\circ} \mathrm{C}\right)$ calculated from the corresponding XRD line broadening.

According to the XRD pattern, $\alpha-\mathrm{Fe}_{2} \mathrm{O}_{3}-\mathrm{In}_{2} \mathrm{O}_{3}$ (9:1) composite consists of $\alpha-\mathrm{Fe}_{2} \mathrm{O}_{3}$ phase with increased parameters of unit cell (see Fig. 6). The increasing of the cell parameters is caused by the substitution of part of $\mathrm{Fe}$ (III) ions with In(III) ones. Besides, the $\mathrm{X}$-ray reflexes assigned to the $\alpha-\mathrm{Fe}_{2} \mathrm{O}_{3}$ phase are strongly broadened; this fact can be explained both by the nano-dimension of particles and the high defectiveness of the crystalline structure.

It was also assumed that $\alpha-\mathrm{Fe}_{2} \mathrm{O}_{3}$ phase, obtained through the oxidation of $\gamma-\mathrm{Fe}_{2} \mathrm{O}_{3}$ phase, is quite different from $\alpha$ $\mathrm{Fe}_{2} \mathrm{O}_{3}$ phase prepared by thermal dehydration of $\alpha$-modification of iron(III) hydroxide. The irregularity of $\mathrm{Fe}(\mathrm{III})$ state within $\alpha-\mathrm{Fe}_{2} \mathrm{O}_{3}-\mathrm{In}_{2} \mathrm{O}_{3}$ (9:1) can be observed from the Mössbauer pattern recorded from the indicated sample.

Table 4

The most promising gas-sensitive materials recommended for fabricating of highly selective sensors and their structural peculiarities

\begin{tabular}{lclll}
\hline Sample & $T\left({ }^{\circ} \mathrm{C}\right)$ & $\begin{array}{l}\text { Detected } \\
\text { gas }\end{array}$ & $\begin{array}{l}\text { Phase } \\
\text { composition }\end{array}$ & $\begin{array}{l}\text { Particle } \\
\text { size }(\mathrm{nm})\end{array}$ \\
\hline$\gamma-\mathrm{Fe}_{2} \mathrm{O}_{3}-\mathrm{In}_{2} \mathrm{O}_{3}(9: 1)$ & 135 & $\mathrm{O}_{3}$ & $\gamma-\mathrm{Fe}_{2} \mathrm{O}_{3}{ }^{\mathrm{a}}$ & 25 \\
& & & $\mathrm{C}-\mathrm{In}_{2} \mathrm{O}_{3}$ & 25 \\
& & & $\alpha-\mathrm{Fe}_{2} \mathrm{O}_{3}$ & $10-15$ \\
$\alpha-\mathrm{Fe}_{2} \mathrm{O}_{3}-\mathrm{In}_{2} \mathrm{O}_{3}(9: 1)$ & $70-100$ & $\mathrm{NO}_{2}$ & $\gamma-\mathrm{Ce}_{2} \mathrm{O}_{3}$ & $25-30$ \\
$\gamma-\mathrm{Fe}_{2} \mathrm{O}_{3}$ & 250 & $\mathrm{C}_{2} \mathrm{H}_{5} \mathrm{OH}$ & $\gamma-8$ \\
$\gamma-\mathrm{Fe}_{2} \mathrm{O}_{3}-\mathrm{In}_{2} \mathrm{O}_{3}(1: 1)$ & $70-100$ & $\mathrm{NO}_{2}$ & $\mathrm{C}-\mathrm{In}_{2} \mathrm{O}_{3}{ }^{a}$ & $7-8$ \\
& 300 & $\mathrm{C}_{2} \mathrm{H}_{5} \mathrm{OH}$ & $\gamma-\mathrm{Fe}_{2} \mathrm{O}_{3}$ & 5 \\
\hline
\end{tabular}

Temperature of annealing is $300^{\circ} \mathrm{C}$. ${ }^{a}$ Main phase. 


\section{ARTICLE IN PRESS}

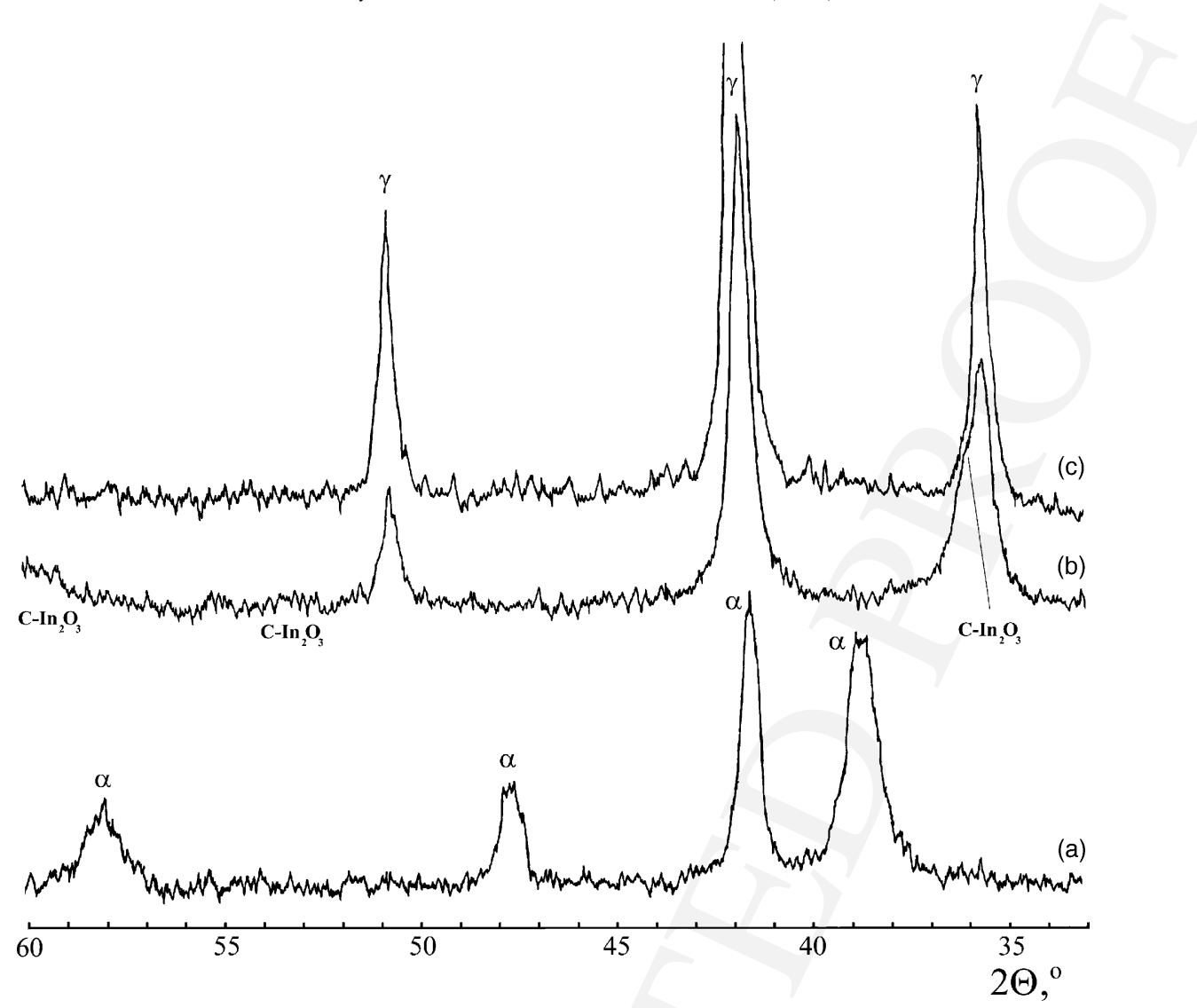

Fig. 6. XRD patterns recorded from (a) $\alpha-\mathrm{Fe}_{2} \mathrm{O}_{3}-\mathrm{In}_{2} \mathrm{O}_{3}$ (9:1), (b) $\gamma-\mathrm{Fe}_{2} \mathrm{O}_{3}-\mathrm{In}_{2} \mathrm{O}_{3}$ (9:1) and (c) $\gamma-\mathrm{Fe}_{2} \mathrm{O}_{3}$ samples. Temperature of annealing is $300{ }^{\circ} \mathrm{C}$.

Regarding to magnetic properties, the oxides prepared by the sol-gel technology differ from the corresponding standard sample (Fig. 7a and b). We can distinguish three types of $\mathrm{Fe}(\mathrm{III})$ ions with discriminate parameters in Mössbauer spectrum of $\alpha-\mathrm{Fe}_{2} \mathrm{O}_{3}-\mathrm{In}_{2} \mathrm{O}_{3}$ composite (Table 5).

(i) About $78 \%$ of total amount of $\mathrm{Fe}$ (III) ions is characterized by magnetic parameters and coordination environment typical for $\mathrm{Fe}(\mathrm{III})$ ions within amorphous or poorly crystallized $\alpha-\mathrm{Fe}_{2} \mathrm{O}_{3}$ phase.

Table 5

Parameters of Mössbauer spectra recorded from iron-containing samples at $298 \mathrm{~K}$

\begin{tabular}{llcc}
\hline Sample & $\delta\left(\mathrm{mm} \mathrm{s}^{-1}\right)$ & $\Delta\left(\mathrm{mm} \mathrm{s}^{-1}\right)$ & $B(\mathrm{~T})$ \\
\hline$\alpha-\mathrm{Fe}_{2} \mathrm{O}_{3}-\mathrm{In}_{2} \mathrm{O}_{3}(9: 1)\left(300^{\circ} \mathrm{C}\right)$ & $0.38(78)$ & 0.08 & 50.7 \\
& $0.53(15)$ & 0 & 0 \\
& $0.22(7)$ & 0.69 & 0 \\
$\gamma-\mathrm{Fe}_{2} \mathrm{O}_{3}-\mathrm{In}_{2} \mathrm{O}_{3}(9: 1)\left(300^{\circ} \mathrm{C}\right)$ & 0.33 & 0.02 & 48.6 \\
$\gamma-\mathrm{Fe}_{2} \mathrm{O}_{3}($ sol $)\left(300{ }^{\circ} \mathrm{C}\right)$ & 0.34 & -0.03 & 49.1 \\
$\gamma-\mathrm{FeOOH}^{\circ}\left(300^{\circ} \mathrm{C}\right)$ & 0.33 & 0.78 & 0 \\
$\alpha-\mathrm{Fe}_{2} \mathrm{O}_{3}$ (amorphous) $\left(300^{\circ} \mathrm{C}\right)$ & 0.39 & 0.09 & 50.7 \\
$\gamma-\mathrm{Fe}_{2} \mathrm{O}_{3}$ (standard sample) & 0.34 & -0.05 & 49.6 \\
$\alpha-\mathrm{Fe}_{2} \mathrm{O}_{3}$ (standard sample) & 0.47 & 0.24 & 51.8 \\
& 0.38 & 0.12 & 51.5 \\
\hline
\end{tabular}

The values in parentheses are in percent. (ii) About $15 \%$ of $\mathrm{Fe}(\mathrm{III})$ has a cubic coordination environment. This type of coordination can be assigned to isolated $\mathrm{Fe}(\mathrm{III})$ ions in octahedral environment of oxygen, which is typical for cubic $\operatorname{In}_{2} \mathrm{O}_{3}$ modification. Moreover, $\gamma-\mathrm{Fe}_{2} \mathrm{O}_{3}$ can possess cubic structure as well.

Under sample heating at $150-200{ }^{\circ} \mathrm{C}$, the $\gamma-\mathrm{Fe}_{2} \mathrm{O}_{3}$ phase remains stable within $\alpha-\mathrm{Fe}_{2} \mathrm{O}_{3}-\mathrm{In}_{2} \mathrm{O}_{3} \quad$ (9:1) 232 sample obtained from $\mathrm{Fe}(\mathrm{II})$ precursor, which was 233 used in this study. The annealing of the composite at 234 temperatures over $250{ }^{\circ} \mathrm{C}$ leads to the transformation of 235 $\gamma-\mathrm{Fe}_{2} \mathrm{O}_{3}$ phase doped with $\mathrm{In}(\mathrm{III})$ ions into $\alpha-\mathrm{Fe}_{2} \mathrm{O}_{3}$, whereas individual $\gamma-\mathrm{Fe}_{2} \mathrm{O}_{3}$ oxide remains stable regarding $\gamma-\mathrm{Fe}_{2} \mathrm{O}_{3} \rightarrow \alpha-\mathrm{Fe}_{2} \mathrm{O}_{3}$ phase transformation up to $485^{\circ} \mathrm{C}$. Moreover, $\gamma-\mathrm{Fe}_{2} \mathrm{O}_{3}$ phase within $\gamma$ $\mathrm{Fe}_{2} \mathrm{O}_{3}-\mathrm{In}_{2} \mathrm{O}_{3}$ composite is stable at temperatures up to $700{ }^{\circ} \mathrm{C}$ depending on the component ratio. Thus, in the case of $\gamma-\mathrm{Fe}_{2} \mathrm{O}_{3}-\mathrm{In}_{2} \mathrm{O}_{3}$ (9:1) sample, the $\gamma-\mathrm{Fe}_{2} \mathrm{O}_{3} \rightarrow \alpha$ $\mathrm{Fe}_{2} \mathrm{O}_{3}$ phase transformation occurs at about $500{ }^{\circ} \mathrm{C}$.

(iii) A minor part of $\mathrm{Fe}$ (III) ions (7\%) can be only assigned to $\gamma-\mathrm{FeOOH}$ structure.

Therefore, the sample based on $\gamma-\mathrm{Fe}_{2} \mathrm{O}_{3}-\mathrm{In}_{2} \mathrm{O}_{3}$ (9:1) consists of $\gamma-\mathrm{Fe}_{2} \mathrm{O}_{3}$; a small amount of $\mathrm{C}-\mathrm{In}_{2} \mathrm{O}_{3}$ phase is also present (See Fig. 6). In this case, the grain size is greater than in the case of $\alpha-\mathrm{Fe}_{2} \mathrm{O}_{3}$ sample with the same composition. Mössbauer pattern of $\gamma-\mathrm{Fe}_{2} \mathrm{O}_{3}-\mathrm{In}_{2} \mathrm{O}_{3}$ system differs from that one recorded from the standard sample by broad3 34
235 

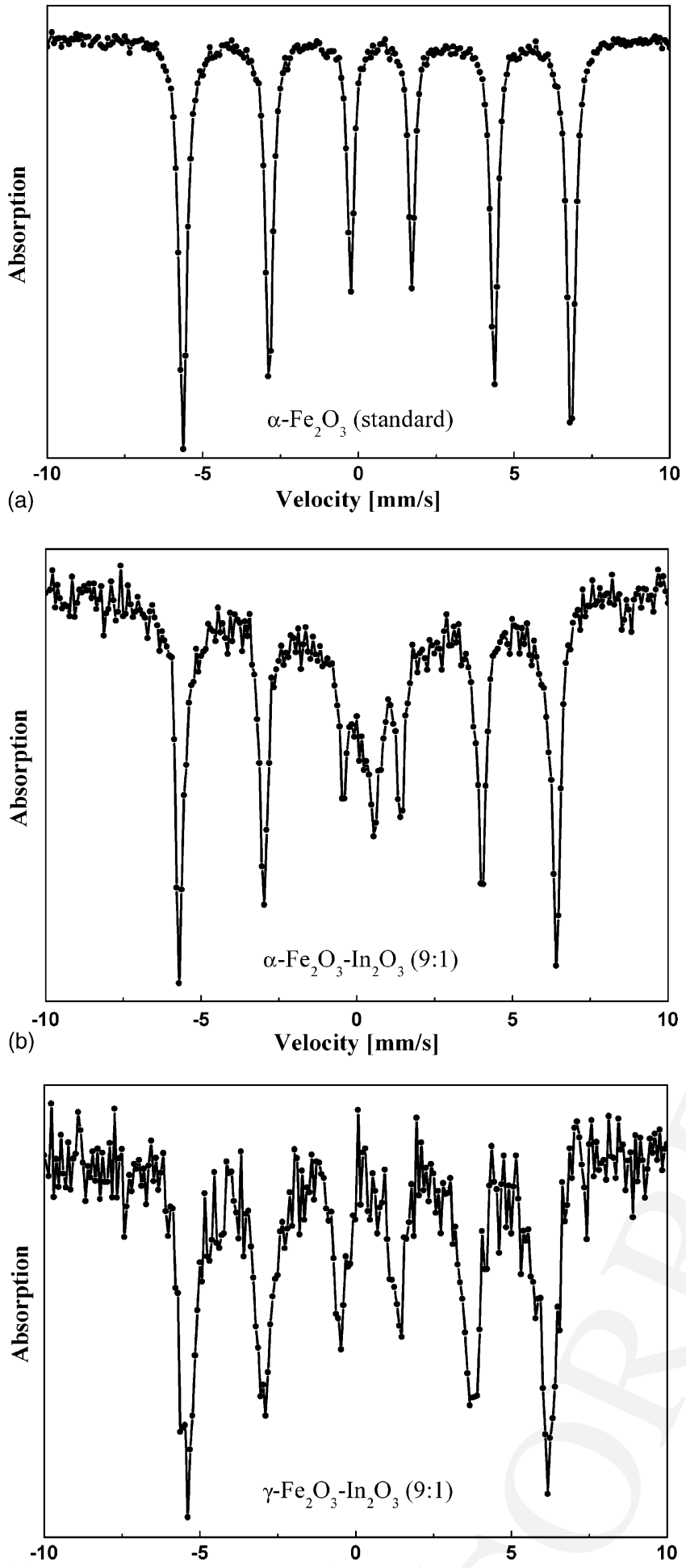

(c)

Velocity $[\mathrm{mm} / \mathrm{s}]$

Fig. 7. Mössbauer spectra recorded from (a) $\alpha-\mathrm{Fe}_{2} \mathrm{O}_{3}$ standard, (b) $\alpha$ $\mathrm{Fe}_{2} \mathrm{O}_{3}-\mathrm{In}_{2} \mathrm{O}_{3}(9: 1)$ and (c) $\gamma-\mathrm{Fe}_{2} \mathrm{O}_{3}-\mathrm{In}_{2} \mathrm{O}_{3}(9: 1)$ samples at $298 \mathrm{~K}$. environment or $\mathrm{Fe}-\mathrm{O}$ bond ionicity shift in the presence of In(III) ions within $\gamma-\mathrm{Fe}_{2} \mathrm{O}_{3}$ crystal lattice.

\subsection{Regularities of certain gas detection}

On the base of the obtained results we made an attempt to find the correlation between gas-sensitive behavior of $\mathrm{Fe}_{2} \mathrm{O}_{3}-\mathrm{In}_{2} \mathrm{O}_{3} / \mathrm{In}_{2} \mathrm{O}_{3}$ and $\mathrm{Fe}_{2} \mathrm{O}_{3}-\mathrm{In}_{2} \mathrm{O}_{3}$ active layers and their structural features.

\subsubsection{Nitrogen dioxide}

In order to obtain an advanced sensor for $\mathrm{NO}_{2}$ detection, it is necessary to use materials which are characterized by high dispersion and defectiveness [10]. It is well known that doping of $\mathrm{In}_{2} \mathrm{O}_{3}$ with $\mathrm{Ni}(\mathrm{II})$ and $\mathrm{Mo}(\mathrm{VI})$ ions results in increasing of $\mathrm{In}_{2} \mathrm{O}_{3}$ based sensor sensitivity to $\mathrm{NO}_{2}[7,9]$. Addition of these ions leads to the formation of strongly defective $\mathrm{In}_{2} \mathrm{O}_{3}$ structure and favors the decreasing of oxide grains.

Similar changes were observed for $\alpha-\mathrm{Fe}_{2} \mathrm{O}_{3}$ oxide doped with $\mathrm{In}(\mathrm{III})$ ions. In the case of $\alpha-\mathrm{Fe}_{2} \mathrm{O}_{3}-\mathrm{In}_{2} \mathrm{O}_{3}$ (9:1) sample, together with $\alpha-\operatorname{In}_{x} \mathrm{Fe}_{2-x} \mathrm{O}_{3}$ solid solution, it is possible to distinguish other structural elements based on $\mathrm{Fe}_{2} \mathrm{O}_{3}$. We have yet not succeeded in identification of the supposed additional phases using XRD analysis, but the presence of several types of Fe(III) ions was confirmed by Mössbauer spectroscopy. An increased $\mathrm{Fe}-\mathrm{O}$ bond length and the distortion of octahedral environment of $\mathrm{Fe}$ (III) ions favors the effective adsorption of $\mathrm{NO}_{2}$, whereas the presence of two types of ions (Fe(III) and $\mathrm{In}(\mathrm{III}))$ within the $\alpha-\mathrm{In}_{x} \mathrm{Fe}_{2-x} \mathrm{O}_{3}$ solid solution facilitates to a certain extent the desorption of oxygen in comparison with the simple oxides. Thus, high sensitivity of $\alpha-\mathrm{Fe}_{2} \mathrm{O}_{3}-\mathrm{In}_{2} \mathrm{O}_{3}$ films to $\mathrm{NO}_{2}$ at low temperatures can be explained by high system dispersion and the presence of $\mathrm{Fe}$ (III) ions in irregular coordination environment which is evoked by doping of $\mathrm{Fe}_{2} \mathrm{O}_{3}$ phase with In(III) ions.

The growth of the response value of $\gamma-\mathrm{Fe}_{2} \mathrm{O}_{3}-\mathrm{In}_{2} \mathrm{O}_{3} / \mathrm{In}_{2} \mathrm{O}_{3}$ sensor with the increasing of $\operatorname{In}_{2} \mathrm{O}_{3}$ content from 10 to $50 \%$ within composite can be connected with grain size decreasing and the formation of highly defective sample with the high specific surface.

\subsubsection{Ozone}

The most important requirement for the efficient detection of ozone at low temperatures $\left(70-100{ }^{\circ} \mathrm{C}\right)$ is the suitable catalytic activity of an oxide in reaction of ozone decomposition:

$\mathrm{O}_{3} \rightarrow \mathrm{O}_{2}+\mathrm{O}$.

Iron oxide is known to be an active catalyst in this process; the main factors which influence the catalytic ability of $\mathrm{Fe}_{2} \mathrm{O}_{3}$ are oxidation state of a sample and its dispersion [11]. The oxidation level of the sample is closely related to its activity. Thus, $\alpha-\mathrm{Fe}_{2} \mathrm{O}_{3}$ possesses better catalytic properties than $\gamma-\mathrm{Fe}_{2} \mathrm{O}_{3}$.

With regards to $\mathrm{O}_{3}, \alpha-\mathrm{Fe}_{2} \mathrm{O}_{3}$ phase demonstrates considerably higher sensitivity in comparison with $\gamma-\mathrm{Fe}_{2} \mathrm{O}_{3}$ species
260 
[6]. However, the origin of different behavior of these systems is still unclear. In the case of $\gamma-\mathrm{Fe}_{2} \mathrm{O}_{3}-\mathrm{In}_{2} \mathrm{O}_{3}$ composite, the presence of separate $\gamma-\mathrm{Fe}_{2} \mathrm{O}_{3}$ phase probably provides an elevated activity of this sample towards $\mathrm{O}_{3}$ at low temperatures. In contrast, $\alpha-\mathrm{Fe}_{2} \mathrm{O}_{3}-\mathrm{In}_{2} \mathrm{O}_{3}$ sample consists of $\mathrm{In}(\mathrm{III})-\alpha-\mathrm{Fe}_{2} \mathrm{O}_{3}$ solid solution; catalytic ability of $\alpha-\mathrm{Fe}_{2} \mathrm{O}_{3}$ phase in $\mathrm{O}_{3}$ decomposition reaction is insignificant.

Since at low temperatures a limiting stage of the reaction is removing of chemisorbed oxygen, the presence of the second phase $\left(\mathrm{In}_{2} \mathrm{O}_{3}\right)$ in $\gamma-\mathrm{Fe}_{2} \mathrm{O}_{3}$ is capable to facilitate the desorption of oxygen from the oxide surface.

At temperatures higher than $100{ }^{\circ} \mathrm{C}$ decomposition of ozone is passing effectively in gas phase according to the following equation:

$\mathrm{O}_{3} \rightarrow \mathrm{O}_{2}+\mathrm{O}$

Detection of $\mathrm{O}_{3}$ is going at $\mathrm{Fe}_{2} \mathrm{O}_{3}-\mathrm{In}_{2} \mathrm{O}_{3}$ through the adsorption of not molecular $\left(\mathrm{O}_{2}\right)$ but atomic $(\mathrm{O})$ oxygen species. Thus, one can explain the observed differences in optimal detecting temperature of $\mathrm{O}_{3}$ using $\alpha-\mathrm{Fe}_{2} \mathrm{O}_{3}-\mathrm{In}_{2} \mathrm{O}_{3}$ and $\gamma-\mathrm{Fe}_{2} \mathrm{O}_{3}-\mathrm{In}_{2} \mathrm{O}_{3}$ composites by change of detection mechanism as a result of operating temperature variation.

\subsubsection{Alcohol}

The sensors based on heterojunction oxide structures show considerable response in alcohol (ethanol, methanol) media. The heterojunction between the oxide and the solid solution phases appears to be very active in course of both adsorption and oxidation of alcohol.

It is shown in [12] that the presence of two types of centers possessing the discriminate redox and acid-base properties and participating in transformation processes of alcohol molecule is an essential requirement to achieve high sensor response when alcohol detection is mentioned. Alcohol detection is considered as a multi-step process involving both reductive-oxidative and acid-base interactions. Oxide phases within the composite differ by oxygen-oxide surface bonding energy which can be the relative measure of oxide activity in the oxidation reactions. The reactivity of oxides in acid-base reactions depends on electronegativity of metal cation. The electronegativity is the measure of Lewis acid site activity. Thus, the centers of one type can mainly participate in adsorption-desorption processes of alcohol molecules, whereas complete oxidation of intermediates is going effectively at the centers of another type.

Increased response of $\gamma-\mathrm{Fe}_{2} \mathrm{O}_{3}-\mathrm{In}_{2} \mathrm{O}_{3}(1: 1) / \mathrm{In}_{2} \mathrm{O}_{3}$ sample as compared with $\gamma-\mathrm{Fe}_{2} \mathrm{O}_{3}-\mathrm{In}_{2} \mathrm{O}_{3}$ can be explained by the presence of an higher contact interface between $\mathrm{In}_{2} \mathrm{O}_{3}$ and $\gamma$ $\mathrm{Fe}_{2} \mathrm{O}_{3}$ phases within $\gamma-\mathrm{Fe}_{2} \mathrm{O}_{3}-\mathrm{In}_{2} \mathrm{O}_{3}$ composite.

\section{Conclusions}

The sensing characteristics of $\mathrm{Fe}_{2} \mathrm{O}_{3}-\mathrm{In}_{2} \mathrm{O}_{3}$ sensors towards gases of different chemical nature are found to be very promising. It is important to note that the most

sensitive materials consist of two layers. In this case, the specific heterojunction is formed providing the differentiation between receptor and transducer functions. As it was established, $\gamma-\mathrm{Fe}_{2} \mathrm{O}_{3}-\mathrm{In}_{2} \mathrm{O}_{3}$ (9:1) composite is highly sensitive to $\mathrm{O}_{3}$; on the contrary, the $\alpha-\mathrm{Fe}_{2} \mathrm{O}_{3}-\mathrm{In}_{2} \mathrm{O}_{3}(1: 1)$ system possesses the highest sensitivity to $\mathrm{NO}_{2}$. The $\gamma-\mathrm{Fe}_{2} \mathrm{O}_{3}-\mathrm{In}_{2} \mathrm{O}_{3}$ sensor is sensitive to $\mathrm{C}_{2} \mathrm{H}_{5} \mathrm{OH}$ at considerably higher temperatures $\left(250-300{ }^{\circ} \mathrm{C}\right)$ but it is practically inactive to detect the other reducing gases $\left(\mathrm{CH}_{4}, \mathrm{CO}, \mathrm{NH}_{3}\right)$.

An attempt to establish the correlation between particular structural features of the samples and their gas-sensitive behavior was made in this paper.

\section{Acknowledgements}

This work has been performed in the frame of the EC Program "INCO-COPERNICUS-II" (GASMOH Project \#ICA2-CT-2000-10041).

\section{References}

[1] Y. Nakatani, M. Matsuoka, Effect of sulfate ion on gas sensitive properties of $\alpha-\mathrm{Fe}_{2} \mathrm{O}_{3}$ ceramics, Jpn. J. Appl. Chem. (1982) L758-L760.

[2] T.G. Newor, St.P. Yordanov, Ceramic gas sensors: technique and application, Techmomic, Lancosh, 1996.

[3] W. Chang, D. Lee, Characteristics of $\alpha-\mathrm{Fe}_{2} \mathrm{O}_{3}$ thick film gas sensors, Thin Solid Films 200 (1991) 329-339.

[4] O.K. Tan, W. Zhu, Q. Yan, L.B. Kong, Size effect and gas sensing characteristics of nanocrystalline $x \mathrm{SnO}_{2}-(1-x) \alpha-\mathrm{Fe}_{2} \mathrm{O}_{3}$ ethanol sensors, Sens. Actuators B 65 (2000) 361-365.

[5] T. Takada, K. Suzuki, M. Nakane, Highly sensitive ozone sensor, Sens. Actuators B 13-14 (1993) 404-407.

[6] F.H. Chibirova, E.E. Gutman, Structural defects and gas-sensitive properties of some semiconductor metal oxides, Rus. J. Phys. Chem. 74 (9) (2000) 1555-1561.

[7] A. Gurlo, N. Bârsan, M. Ivanovskaya, U. Weimar, W. Göpel, $\mathrm{In}_{2} \mathrm{O}_{3}$ and $\mathrm{In}_{2} \mathrm{O}_{3}-\mathrm{MoO}_{3}$ thin film semiconductor sensors: interaction with $\mathrm{NO}_{2}$ and $\mathrm{O}_{3}$, Sens. Actuators B 47 (1998) 92-99.

[8] M. Ivanovskaya, A. Gurlo, P. Bogdanov, Mechanism of $\mathrm{O}_{3}$ and $\mathrm{NO}_{2}$ detection and selectivity of $\mathrm{In}_{2} \mathrm{O}_{3}$ sensors, Sens. Actuators B 77 (2001) 264-267.

[9] M. Ivanovskaya, P. Bogdanov, G. Faglia, G. Sberveglieri, The features of thin film and ceramic sensors at the detection of $\mathrm{CO}$ and $\mathrm{NO}_{2}$, Sens. Actuators B 68 (2000) 344-350.

[10] P. Bogdanov, M. Ivanovskaya, E. Comini, G. Faglia, G. Sberveglieri, Effect of nickel ions on sensitivity of $\mathrm{In}_{2} \mathrm{O}_{3}$ thin film sensors to $\mathrm{NO}_{2}$, Sens. Actuators B 57 (1999) 153-158.

[11] V.V. Lunin, M.P. Popovich, S.N. Tkachenko, The Physical Chemistry of Ozone, Moscow State University, Moscow, 1998.

[12] M. Ivanovskaya, D. Kotsikau, G. Faglia, P. Nelli, Influence of chemical composition and structural factors of $\mathrm{Fe}_{2} \mathrm{O}_{3}-\mathrm{In}_{2} \mathrm{O}_{3}$ based sensors on their selectivity and sensitivity to ethanol, in: Proceedings of the International Conference on Eurosensors XVI, Prague, Czech Republic, 15-18 September 2002.

381 382 383

\section{Biographies}

Maria Ivanovskaya received her degree in chemistry in 1980 from Belarus State University in the field of photochemistry. Till 1988 she carried out investigations in the field of solid state photochemistry $\left(\mathrm{TiO}_{2}, \mathrm{ZnO}\right.$,

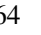
65 66

\section{,} 8

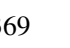
"n (n)

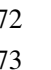
4 15

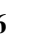

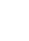

,


$\mathrm{BiOBr}$ ) and chemistry of photographic processes. Since 1989 she has been worked in Scientific and Research Institute for Physical and Chemical Problems (Belarus State University). Since 1993 she has been occupied a leading research position. Her main scientific interests are solid state chemistry in applications to catalysis and semiconductor gas sensors, structural features of nanosized oxides $\left(\mathrm{SnO}_{2}, \mathrm{MoO}_{3}, \mathrm{In}_{2} \mathrm{O}_{3}, \mathrm{Fe}_{2} \mathrm{O}_{3}\right)$ and oxide composites.

Dzmitry Kotsikau graduated from the Belarus State University in 2001 with honors; in the same year entered the post graduate courses. Now he is working in the field of solid state chemistry and semiconductor gas sensors. His main scientific interests are $\mathrm{Fe}_{2} \mathrm{O}_{3}-\mathrm{In}_{2} \mathrm{O}_{3}$ nanosized composites, their structural and gas-sensitive characterization.

Guido Faglia has received an MS degree from the Polytechnic of Milan in 1991 with a thesis on gas sensors. In 1992 he has been appointed as a researcher by the Gas Sensor Laboratory at the University of Brescia. He is involved in the study of the interactions between gases and semiconductor surfaces and in gas sensors electrical characterization. In 1996 he has received the $\mathrm{PhD}$ degree by discussing a thesis on semiconductor gas sensors. In 2000 he has been appointed associate professor in Experimental
Physics at University of Brescia. During his career Guido Faglia has published more than 60 articles on International Journals with referee.

Paolo Nelli received his MS degree in physics from the University of Pavia in 1987, after then he joined the Gas Sensor Laboratory at the University of Brescia, where at present he carries out his research activity on gas sensors. He held a permanent position at the Department of Chemistry and Physics for Materials of the University of Brescia; his interests are focused on the preparation and characterization of gas sensors based on semiconducting metal oxides. He is co-author of about forty papers on gas sensors and material science and 30 presentations at international congresses on the same topics.

Sobir Irkaev graduated from the Tadjik State University in 1965; then he entered the post graduate courses in Moscow State University in 1967. He received his Doctor of Science degree in 1994; Philosophy Doctor degree in 1971. Now he is working at Institute for Analytical Instrumentation of Russian Academy of Science, since 1971 up to now occupies the head of Resonance Laboratory position. He is the author of two monographs: "Nuclear Gamma Resonance", 1970 and "Mössbauer Spectroscopy", St. Petersburg, 1997, over 80 publications and 20 patents. 